\title{
Role Of Ashtang Yoga In Health Tourism - Characteristics And Prospects
}

Pallavi Porwal, Ashish Kumar, Umakant Indoliya, Arunesh Parashar

\begin{abstract}
"Yoga means Union" and "Tourism unites and Yoga provides health, happiness and harmony". These two renowned quotes itself depicts the Role of Yoga-tourism in promoting healthy life style, holistic approach for happiness and global harmony. This study is connected to health tourism describing how techniques of Ashtang yoga are beneficial for healthy life style. The researcher has tried through this paper to bring awareness and change in life style of people through traveling for health i.e. health tourism; Ashtang Yoga being most important technique to achieve holistic health. Health tourism is continuously growing day by day. An Ashtang Yoga technique ensures peace and happiness along with integrated health. The researcher has presented the insight in context of Indian literature but it holds universal appeal. This study shows the importance of key techniques to increase healthy life style through health tourism with especial reference to Ashtang yoga.
\end{abstract}

Key Words - Ashtang Yoga, Health Tourism, Life style 


\section{Introduction}

Health tourism is fastest growing sector worldwide. For getting good health, peaceful mind and healthy life style, a tourist travel one place to another place. With the advent of globalization and culture of consumerism, people begin to travel to make use of wide variety of alternatives that bring satisfaction and healthy living (Jena, \&Manoj K 2014). Now a day's tourists are more sensible of the value of health. They are aware about physical fitness, purity of mind and standard life style. A tourist visits at a tourism destinations for leisure and recreation (Chand Mohinder 2004). The intention of tourist for visiting a tourism destination may change depending up on the nature and environment of place. Hence tourism industry design and create different types of tourism products so as to provide the needs of tourists having different interest. Health tourism is an emerging sector those tourism developed by the competing tourism promoting countries in order to attract tourists traveling with the premier goal of getting healthcare.

\section{Concept of Health Tourism}

Health tourism includes two terms i.e. healthcare and tourism. Health tourism involves different resources of healthcare and tourism. A health tourism destination focuses on its healthcare resources that provide wellness and cure from diseases. Tourism attractions provide peace of mind and relaxation (Walker John R. 2011). Health tourism is transforming a preferred form of leisure and vacationing as it covers a broad scope of health services, medical services and mixed relaxation methods, entertaining and leisure together with well-being and healthcare. Health tourism is also known as medical tourism, wellness tourism, healthcare travel or medical value travel.

\section{Ashtanga Yoga}

Yoga has its history about 5000 years BC as described in Vedic Philosophy and yogic text. Maharshi Patanjali is a great sage combined this path into a Darshan (Philosophy) in his Book PatanjalYoga Sutra. In which he has formulated Yoga as Eight Limbs or Eight Fold path as 'Yam Niyam, Aasan, Pranayam, Pratyahar, Dharna, Dyan and Samadhi'. According to Mahrshi Patanjali, Yoga is a discipline where a shadhak (disciple) practices of various paths. The yoga as declared by Patanjali is written in Sanskrit and given in the form of Sutra (aphorism/ principles) containing main and the important thoughts. The first sutra of the first Pada (part), introduces yoga as following

\section{“AthaYoganushasanam” 1/1 (Patanjal Yog Sutra)}

Yoga means controlling the thought process of the mind. The thoughts, emotions, feelings and ideas arising in the mind are vrittis (nature), which should be disciplined (Vivekananda, S. 1998).

\section{"Yogashchchittavrittinirodhah"1/2 (Patanjal Yog Sutra)}

That means purification of thoughts, emotions, feelings and ideas of the mind. A tourist also wants peace, health and happiness from the tourist destination, hence the sutra of MaharshiPatanjali showing the path of yoga is needed most in health tourism.

Ashtanga Yoga belongs to eight fold of yoga where the first five (Yam, Niyam, Asan, Pranayam and Pratyahar) are called external aids to yoga (BahirangaSadhana) and other three (Dharna, Dhyan and Samadhi) are called internal aids to yoga (AntarangaSadhna). "yamaniyamaāsanaprān̄āyāmapratyāhāradhāran̄ādhyānasam ādhayo-'ștāvañgāni” 2/29 (Patanjal Yog Sutra). The first limb based on a set of ethics and values, which ensures that the sadhak interacts in a harmonious way of life with the surrounding world. The second limb based on the observations, which check that body and mind are not corrupted and polluted once they have been making pure. These two limbs are most valuable assets for a disciple as well as for 
health tourist. With the help of yam and niyama sadhak make sure to go to another fold of Ashtang Yoga.

Table 1. Eight Limbs of Ashtanga yoga

\begin{tabular}{|c|c|c|c|}
\hline S.No. & Eight Limbs & Sub Limbs & Manifestation \\
\hline \multirow{5}{*}{1} & \multirow{5}{*}{$\begin{array}{l}\text { Yam } \\
\text { (Principles or } \\
\text { moral values) }\end{array}$} & Ahimsa & A principle of non-violence \\
\hline & & Satya & A principle of Truthfulness \\
\hline & & Asteya & A principle of non stealing \\
\hline & & Brahmacharya & Continence / Celibacy \\
\hline & & Aparigah & A principle of non-hoarding or non possessiveness \\
\hline \multirow{5}{*}{2} & \multirow{5}{*}{$\begin{array}{c}\text { Niyam } \\
\text { (Personal } \\
\text { Disciplines) }\end{array}$} & Shoucha & Purity \\
\hline & & Santosh & Contentment \\
\hline & & Tapa & Endurance \\
\hline & & Swadhyaya & Self study \\
\hline & & EshwarPranidhan & Dedication \\
\hline 3 & Asan & $\begin{array}{l}\text { Yoga Positions or Yogic } \\
\text { postures }\end{array}$ & $\begin{array}{l}\text { A stable and comfortable posture which helps attain mental } \\
\text { stability }\end{array}$ \\
\hline 4 & Pranayam & Yogic Breathing & Extension and control of breath. \\
\hline 5 & Pratyahar & Withdrawal of Senses & A mental preparation to increase the power of mind. \\
\hline 6 & Dharana & $\begin{array}{l}\text { Concentration on } \\
\text { Object }\end{array}$ & Concentration of mind on one object and its field. \\
\hline 7 & Dhyan & Meditation & the state or practice of meditating \\
\hline 8 & Samadhi & Salvation & $\begin{array}{l}\text { State of Super bliss, joy and merging individual } \\
\text { consciousness in to universal consciousness. }\end{array}$ \\
\hline
\end{tabular}

\section{Yoga and Healthy Life Style}

Yoga is a divine and austere discipline, a part of which, including yogic exercises, breath practices, simple meditation, and the adoption of specific bodily postures, is widely practiced for spiritual enhancements, proper health and relaxation (Maryam S. Atoosa A. \& Mojtaba R. 2013). The term "yogasana” denotes to a posture in which one feels comfortable while keeping the body active internally. The yogis had deeply detected the sitting and standing and walking posture of different animals, birds and suggested different asanas those we are practicing in present time for getting good health. They had examined the effects of different postures of asanas in the laboratory of their own body and established specific asanas which had rejuvenating effects on the whole body-mindsoul system (Ross, T., \& Fontao, M.I. 2008)..

The simplest meaning of 'Yoga' is to unite. The technique of bonding the soul ('atman, chetna') with God (Parm- atma, in a form of good deeds) is known as 'Yoga' in spiritual text and language (Sharma, S. 1998). With the help of Yoga we create a path for better life in which we practices controlling of our thoughts, maintaining our physic, and improves our capabilities. Yogic mantras for healthier life are to practice and detachment. The activities which are required to 
be followed for starting 'Yoga' are known as 'sadhna' (spiritual disciplines). 'Sadhna' is merely a means in that direction (Pandya, P. 2004). It is important in as much as it supports in achieving the goal of life ('sadhya'). In 'Yoga practices' some physical, mental and spiritual activities and techniques are essential to be performed. Their main aim is to healthier and happier life for all also produce and create a mental state of uniting and going for the self-consciousness (soul) with super consciousness (God).

Every condition of life is auspicious and pleasant for us. It is needed to make an effort to keep oneself always happy by adjusting to circumstances (Sharma, S. 2005). If these actions and techniques practiced in daily life with the considering as practice of 'yogasadhna' and make effort is made for the refinement of one's perception, this obtain positive thoughts, good health and peaceful mind. A tourist also wants these things while he is travelling. The main purpose of each and every tourist is that he is getting new perception, new life and new world. The purpose of all of these is simply to improvement inner power and attains piousness, so that a traveler or tourist who is full of impurities wishing purity and happiness may make his journey towards healthy life and spiritual progress.

\section{Refining Healthy Life Style through Yoga}

Harmonious life is the imperial path to learn how to live a meaningful life, and also selfanalysis and observation of one's own life (Steliana L. 2015). A tourist needs to improve and increase personality through yoga because only this is the basis of development, success and glory which after tourism a tourist desire. Healthy, happy andmeaningful life is the most required of aim of every tourist. Whatever be tourist's socioeconomic or spiritual and occupational status, tourist always aspires to have healthy and joyful life. But one must also think of that life and happiness are inner voice with physical, mental and emotional well-being
(Aggarwal2008). Those tourists who give prominence only to physical capability cannot bear decent health unless they are mentally and emotionally well (Brahmavarchas 2007). All are attentive of the problems of the society. A trend of blaming others or situation is prominent and hence a tourist in need of health and happiness travels with same mentality. However, the key is only one to achieve health and happiness i.e. the route of purifying life through yoga leaving no other alternative to it (Pandya, P. 2007).

\section{Benefits and future prospects of astang yoga in health tourism}

Astang Yoga shows new dimensions of life. The aim of Astang Yoga is inner purification, healthy life and doing well to others and society. Tourism is one of the demanding sectors to adopt the potential of Asthng Yoga. Tourist form all world are travelling to lean and practice of it (Sharma Ramkrishan 2001). One can understand the result among tourists and tourism sector with the practice Astang Yoga as following.

\begin{tabular}{cc}
\hline Auto- immunization & Focuses mind \\
\hline Mental hygienic & Create Peace \\
\hline Good Health & $\begin{array}{c}\text { Develop efficiency and } \\
\text { effectiveness }\end{array}$ \\
\hline $\begin{array}{c}\text { Increasing Yoga } \\
\text { Destination }\end{array}$ & $\begin{array}{c}\text { Remove Depression of } \\
\text { Tourists }\end{array}$ \\
\hline $\begin{array}{c}\text { Anxiety } \\
\text { Reduction }\end{array}$ & Remove stress of Tourists \\
\hline & \\
maitreekarunamuditopekshanan \\
sukhaduhkhapunyapunyavishayanan \\
bhavanatashchittaprasadanam \\
Patanjal Yog Sutra- 1/33
\end{tabular}


causing disturbance and mental and physical stress such as families are breaking; education is for earning rather serving society, innovative medical facilities present but poor health prevails and so on (Brahmavarchas, 2009). The reasons behind these all, possibly, one can point that we disconnected ourself with our inner world i.e. sympathy, peace, care, serve etc. A tourist travelling to find a solution of his day to day life, perhaps find AstangYoga is the answer to all these solutions. Yoga is the way to manage Life not only as individual but Humanity as a whole world (Pandya, P. 2016).

\section{Conclusion}

This study aimed to bring awareness to all individuals and tourists that the relation of Astang yoga and health tourism is the potential way for getting connected to one's own life along with society, nation and world and attending best outcome of tourism. Role and future prospects of Astnagyoga in health tourism Ayurveda, yoga and meditation is bringing attention across the world. India has rapidly emerged as a health tourism destination because of its ancient healing practices, alternative therapies, indigenous healing systems and medicinal practicessuch as Ayurveda, Naturopathy, and Pranic Healing to name just a few. It is no wonder that people from all over the world are turning to the Astang yoga for guidance towards a more spiritually satisfying and healthy way of life. In addition, the practices of day to day life and practicing Astangyoga values needs to be further analyzed. The traditional yogic exercise, changes associated with it and emergence of new forms of identity are an interesting area of research which needs further probing. However, the present study raised certain questions in the area of health tourism, holistic health and happy life research which can be further investigated and analyzed.
Pallavi Porwal, Ashish Kumar*, Umakant Indoliya, Arunesh Parashar, Tourism Management, Dev Sanskriti Vishwavidhyalaya, Haridwar, India. *Email ID: ashish.pawar@dsvv.ac.in

\section{References}

Aggarwal, Adarsh Kumar, MeenalGuglani, and Raj Kumar Goel(2008) "Spiritual \& Yoga Tourism: A casestudy on experience of Foreign Tourists visiting Rishikesh, India".

Brahmavarchas (2007) Pragya yoga for healthy and happy life. Haridwar: Shri VedmataGayatri Trust.

Brahmavarchas

Aantarikkayakalpkasunischitvidhan. Mathura:

YugNirmanYojana Press.

Jena, \&Manoj K (2014) Information society and changing family relationships: a case study of Bangalore. Delhi: Jawaharlal nehru university

Chand Mohinder (2004), Basics of Tourism, Kanishka Publishers Distributors, New Delhi 110002

Maryam S. Atoosa A. \&Mojtaba R. (2013) The Effectiveness of Emotional Management Group Training on Children's Self-concept. Social and Behavioral Sciences, Volume 84, Pages 475-478

Pandya, P. (2004) Jivanshailiaadhyatmik ho. AkhandJyoti $1964 \quad$ (10). Mathura: AkhadJyotiSansthan.

Pandya, P. (2004) Reviving the vedic culture of yagya. Mathura: YugNirmanYojana Press.

Pandya, P. (2007) The Enlightened State of Selfawareness. AkhandJyoti 2007 (09). Mathura AkhandJyotiSansthan.

Pandya, P. (2009) Applied science of yagya for health and environment. Haridwar: Shri VedmataGayatri Trust.

Pandya, P. (2016) JivanSadhana - A noble art of living. Haridwar: Shri VedmataGayatri Trust. 
Patanjali Maharshi (2016), Yoga Darshan, Gita Press, Gorakhpur - 273005

Ross, T., \&Fontao, M.I. (2008). The relationship of self- regulation and aggression: an empirical test of personality systems interaction Theory. International journal of offender therapy and comparative criminology, 52 (5) Pages 554-570.

Sharma Ramkrishan (2001), Astanga Yoga Rahashya, RandheerPrakashan, Haridwar - 249401

Sharma, S. (1998) Vigyanauradhyatmaparasparpurak (Vangmay - 23). Mathura AkhandJyotiSansthan.

Sharma, S. (2005) Bina aushdhikekayakalp. Mathura: YugNirmanYojana Press.

Sharma, S. (2005) Samagraswasthaysamvardhankaise ho?. Mathura: YugNirmanYojana Press.

Steliana L. (2015) Age „0” in the Harmonious Development of the Human Being. Social and Behavioral Sciences, Volume 203, Pages 425-428

Sturgess Stephen (2004), The Yoga Book, MohitlalBanarsidass, Delhi 110007

Vivekananda, S. (1998), Yoga Sutras of Patanjali, The Divine Lif Society, shivanandanagar - 249192 Distt. TehriGarhwal, Uttaranchal, Himalayas, India

Vivekanand, S. (2015) Patanjali yoga sutras, Publisher Solar books.

Vivekananda, S. (2016), Patanjali Yoga Darshan, Naveen Shahdara, Delhi - 110032

Walker John R. (2011), Tourism Concepts and Practices, Dorling Kindersley, New Delhi 110017 